\title{
Ocena efektu heterozji cech struktury plonu mieszańców pojedynczych i mieszańców trójliniowych rzepaku (Brassica napus L.)
}

\author{
Estimation of the seed yield traits heterosis for single cross and three-way cross \\ hybrids of oilseed rape (Brassica napus L.)
}

\author{
Joanna Wolko ${ }^{\varpi 1}$, Agnieszka Dobrzycka ${ }^{1}$, Jan Bocianowski ${ }^{2}$ \\ ${ }^{1}$ Instytut Hodowli i Aklimatyzacji Roślin — Państwowy Instytut Badawczy, Oddział w Poznaniu \\ ${ }^{2}$ Uniwersytet Przyrodniczy w Poznaniu \\ 凶e-mail: jwolko@nico.ihar.poznan.pl
}

\begin{abstract}
Rzepak ozimy (Brassica napus L.) jest jedną z najważniejszych roślin oleistych w Polsce i na świecie. Wykorzystanie efektu heterozji poprzez hodowlę odmian mieszańcowych pozwala na zwiększenie plenności rzepaku. Celem niniejszej pracy była ocena efektu heterozji w dwóch populacjach mieszańców rzepaku ozimego. Na posterze zaprezentowano efekt heterozji występujący u mieszańców dla wysokości roślin, długości łuszczyn, liczby nasion w łuszczynie i masy tysiąca nasion. Efekt heterozji mieszańców pojedynczych obliczono względem średniej rodziców (linia DH i linia CMS), a mieszańców trójliniowych — względem średniej dwóch rodziców „bezpośrednich” (mieszaniec CMS/DH i linia $R f o$ ) oraz względem średniej trzech rodziców „pośrednich” (linia DH, linia CMS i linia $R f o$ ). Badane mieszańce wykazywały zarówno dodatni, jak i ujemny wysoce istotny efekt heterozji pod względem badanych cech.
\end{abstract}

\begin{abstract}
Słowa kluczowe: heterozja, cechy struktury plonu, hodowla mieszańcowa, rzepak ozimy
The winter oilseed rape (Brassica napus L.) is one of the most important oil plants in Poland and world wide. Utilization of heterosis has greatly increased rapeseed fertility of hybrid varieties. The aim of this work was to estimate the heterosis in two populations of winter oilseed rape. The poster presents the heterosis responce occurred in plant height, silique length, number of seeds per silique and the thousand seed weight. In single cross hybrids the heterosis response was calculated over the average parents (DH and CMS line), while in three-way cross hybrids over the average of two "direct" parents (CMS/DH hybrid and Rfo line) or over the average of three "indirect" parents (DH, CMS and $R f o$ line). The tested hybrids showed both highly significant positive and negative heterosis in the studied traits.
\end{abstract}

Key words: heterosis, yield-related traits, hybrid breeding, winter oilseed rape

Rzepak ozimy (Brassica napus L.) jest jedną z najważniejszych roślin oleistych w Polsce i na świecie. Ze względu na wzrost zużycia olejów roślinnych, a także wykorzystanie rzepaku na cele paszowe i przemysłowe, zapotrzebowanie na jego nasiona ciągle wzrasta. Plon jest jedną z najważniejszych i zarazem najbardziej skomplikowanych cech roślin uprawnych i kontrolowany jest przez wiele czynników genetycznych i środowiskowych. Jednym ze sposobów na zwiększenie plenności rzepaku jest wykorzystanie efektu heterozji poprzez hodowlę odmian mieszańcowych. Heterozja jest zjawiskiem, w którym potomstwo (F1) zróżnicowanych genetycznie osobników cechuje się zwiększoną biomasą, większym plonem nasion, szybszym rozwojem, lepszą tolerancją na warunki stresowe oraz większą odpornością na choroby. Otrzymywanie mieszańców heterozyjnych ułatwiają systemy męskiej sterylności, z których najbardziej popularny w naszym kraju jest system CMS ogura.
Celem niniejszej pracy była ocena efektu heterozji w dwóch populacjach mieszańców rzepaku ozimego. Badania przeprowadzono na materiale roślinnym składającym się z 182 obiektów: 60 linii podwojonych haploidów (DH) (populacja rodzicielska), 60 mieszańców trójliniowych $(\mathrm{CMS} / \mathrm{bhghDH} \times \mathrm{Rfo})$ oraz linii rodzicielskiej CMS ogura i linii resorującej $z$ genem Rfo, dobranych pod kątem dużego dystansu genetycznego względem linii DH. Mieszańce pojedyncze powstały z krzyżowania linii CMS ogura $\mathrm{z}$ wyjściowymi liniami $\mathrm{DH}$, a mieszańce trójliniowe $-\mathrm{z}$ krzyżowania otrzymanych męskosterylnych mieszańców pojedynczych z linią restorującą Rfo. Doświadczenia polowe w układzie bloków losowanych w trzech powtórzeniach obejmowały dwa sezony wegetacyjne: $2014 / 15$ i $2015 / 16$. W warunkach polowych oceniano cechy fenotypowe związane $\mathrm{z}$ długością kwitnienia, morfologią roślin oraz cechami plonotwórczymi. Na posterze zaprezentowano efekt heterozji występujący $u$ mieszańców dla wysokości roślin, długości 
łuszczyn, liczby nasion w łuszczynie i masy tysiąca nasion. Efekt heterozji mieszańców pojedynczych obliczono względem średniej rodziców (linia DH i linia CMS), a mieszańców trójliniowych — względem średniej dwóch rodziców „bezpośrednich” (mieszaniec CMS/DH i linia Rfo) oraz względem średniej trzech rodziców „pośrednich” (linia DH, linia CMS i linia Rfo).

Badane mieszańce wykazywały zarówno dodatni, jak i ujemny wysoce istotny efekt heterozji pod względem badanych cech. Najwięcej mieszańców przejawiało dodatni efekt heterozji pod względem wysokości roślin, co świadczy o ich zwiększonym wigorze.
Dodatni efekt heterozji obserwowano u większej liczby mieszańców trójliniowych niż pojedynczych (dotyczy to wysokości roślin, długości łuszczyn i liczby nasion w łuszczynie). Znajduje to odbicie również w wielkości tego efektu dla wyżej wymienionych cech. Był on większy u mieszańców trójliniowych niż u pojedynczych. Odwrotna sytuacja miała miejsce w przypadku masy tysiąca nasion (MTN), gdzie większość mieszańców trójliniowych przejawiała ujemny efekt heterozji pod względem tej cechy. Dodatkowo, dla MTN ujemny efekt był większy u mieszańców pojedynczych, a mniejszy u trójliniowych. Może to być następstwem występującej zazwyczaj negatywnej korelacji pomiędzy liczbą nasion w łuszczynie a masą tysiąca nasion.

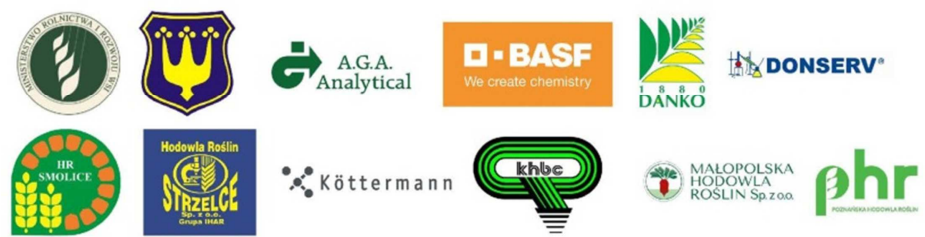

